\title{
LATE MORPHOLOGICAL CHANGES IN THE MOLAR PULP OF WISTAR RATS WITH ALLOXAN
} INDUCED DIABETES

\author{
RADUJKOVIĆ-KUBUROVIĆ GORDANA*, VUKOBRATOVIĆ $S^{*}$ and JOVOVIĆ ĐURĐICA** \\ *Institute of Histology, Faculty of Stomatology, Belgrade \\ **Insitute for Medical Research, Belgrade \\ (Received 4. May 2003)
}

The aim of this study was examination of late changes in the dental pulp of rats with experimental diabetes. The experiment involved 36 male albino rats, initially 35 days old and $89.45 \pm 9.95 \mathrm{~g}$ body wight. The animals were separated into 6 equal groups. The first (T1), third (T2) and fifth (T3) groups of animals were given a single dose of alloxan tetrahydrate, approximately $80 \mathrm{mg} / \mathrm{kg}$ body weight. Just before the application, the substance was dissolved in physiological saline, and each animal was given $1 \mathrm{ml}$ in the tail vein. The second (C1), fourth (C2), and sixth (C3) group of animals were used as appropriate control groups and received $1 \mathrm{ml}$ of physiological saline injection. Body weights were measured and glycemia was checked weekly. The animals in groups T1 and C1 were sacrificed on the 63rd day, groups T2 and C2 on the 95th day and groups $\mathrm{T} 3$ and $\mathrm{C} 3$ on the 125th day by decapitation. The block of mandibular molars was taken for histological examination. The results of histological examinations showed stasis, in microcirculation, as well as in large blood vessels of the pulp, and necrosis of the pulp tissue in animals after 63 days of experimental diabetes. Pulps of the animals killed after 95 days showed, besides massive pulp necrosis, abscess forms localized in the mesial horn of the pulp. This evidence was not present in every animal from group T2. Pulps of the animals sacrificed after 125 days showed hydropic degeneration of the pulp with massive and diffuse presence of vacuoles in odontoblasts.

Key words: Diabetes mellitus, alloxan, dental pulp, blood vessels

\section{INTRODUCTION}

Diabetes mellitus, one of the oldest and in detail described disease of human medicine still represents an illness that draws the attention of medical researchers. Many of complications in different organ systems (Krahl,1975; Engels et al.,1999; van Zwieten,1999; Masuda et al.,1999; van Buren et al.,1998) which accompany this disease have also been widely examined. Nevertheless, there are locations where there are certain difficulties in taking material, which represent an insufficiently examined area that can be struck by this disease. One of these zones is the dental pulp. It is enclosed in a strong mineral structure, so demineralisation 
is necessary before analysis of histological preparations. Dental pulp is a specialised, well vascularized tissue. It has a branching vascular structure of terminal character. Each insult that can provoke damage or occlusion of blood vessel walls damages the dental pulp tissue. As diabetes mellitus is accompanied by vasculopathia, as a regular complication (Devečerski,1982; Zaneti et al.,2000; Masuda et al.,1999; Murat et al.,1999; Hopfner et al.,1999; Kobayashi et Kamata 1999; Kobayashi et al.,1999; van Buren et al.,1998 ), it may be expected that pulp blood vessels will react first in the microcirculation. Surrounding pulp tissue will also show pathological changes because of the disturbed blood circulation.

\section{MATERIAL AND METHODS}

Male albino, Wistar rats (Rattus norvegicus) of body weight $89.45 \pm 9.95 \mathrm{~g}$ and 35 days of age were used as the experimental model. To satisfy the standard conditions for alloxan diabetes, the animals were fasted for 24 hours before the beginning of the experiment, but had free access to water. During the experiment the animals were given totally granulated standard food for laboratory rats (mixture $\mathrm{Pa} 20 \mathrm{~g}$ per animal), from the Veterinarian Institute in Subotica (SOUR "Agros").

The animals were divided into six experimental groups of six animals each:

- First group (T1)

animals treated with alloxan were sacrificed 63 days from the beginning of the experiment.

- Second group (C1)

animals not treated with alloxan were sacrificed 63 days from the beginning of the experiment.

- Third group (T2)

animals treated with alloxan were sacrificed 95 days from the beginning of the experiment.

- Fourth group (C2)

animals not treated with alloxan were sacrificed 95 days from the beginning of the experiment.

- Fifth group (T3)

animals treated with alloxan were sacrificed 125 days from the beginning of the experiment.

- Sixth group (C3)

animals not treated with alloxan were sacrificed 125 day from the beginning of the experiment.

The eighteen animals from the treated groups were given alloxan tetrahydrate $\left[\left(\mathrm{C}_{4} \mathrm{H}_{2} \mathrm{~N}_{2} \mathrm{O}_{4} \cdot 4 \mathrm{H}_{2} \mathrm{O}\right), \mathrm{Mw}=214.12 \mathrm{~g} / \mathrm{mol}\right]$ at approximately $80 \mathrm{mg} / \mathrm{kg}$ body weight. The substance was dissolved in physiological saline before application and each animal was injected with $1 \mathrm{ml}$ of solution in the tail vein. The eighteen 
animals from the control groups received $1 \mathrm{ml}$ of physiological saline in the tail vein.

During the experiment:

- body weight was determined at the beginning of the experimental period and later every 7th day on a technical balance ("Mettler PS 100"), with the precision of $0.1 \mathrm{~g}$.

- glucemia was determined by a polygraphic method, using a microhematocrit reader ( MSE) at the beginning of the experimental period and afterwards every 7 th day from the time of alloxan administration

- histological examination was done after sacrificing the animal by decapitation, without anesthesia. The part with the lower block of molars was separated with a diamond tiled whetstone from the rest of the mandibula. Tissues were fixed in $4 \%$ neutral buffered formalin. After fixation for 18 days, blocks of molars were rinsed and then sunk in bottles with $20 \%$ neutral solution of EDTA (ethylene diamine tetracetate). The decalcification lasted for 57 days approximately, and the degree of decalcification was controlled radiographically. Dehydration was done in a series of alcohols, clearing in xylol, and embedding in paraplast. Serial sections of preparations for histological analysis were cut on a microtome ("Szankos"), and every fourth sample, 3 micrometers thick, was stained by the following methods: HE (hematoxylin eosin), PAS (Periodic Acid Schiff), Grosman Mallory. Pathohistological analysis of the coronary part of lower molar pulp preparations was made under a microscope ("Leitz Wetzlar"). The results were statistically analysed and the significance of differences between mean values calculated by Student's t-test (Wallenstein,1980).

\section{RESULTS}

The mean values for body weight of the alloxan treated animals were less than those in the control groups and showed significant differences $(p<0.001)$, already on day 7 of the experimental period. These statistically significant differences increased steadily during the whole experimental period (Figure 1).

Compared with the control groups there was statistically significantly higher glycemia $(p<0.001)$ in the alloxan-treated groups 24 hours after application. Measurement at 0 and 7 days only, mentioned in methods and given in Figure. Glycemia increased 5-fold in the first week in the treated groups and then remained within a similar range to the end of the experiment. Values in the control groups stayed around 4-5mmol/l (Figure 2).

Histological analysis of the pulp of the first mandibular molar from a rat in group $\mathrm{C} 1$ is show in Figure 3. Changes that led to increased stasis in large blood vessels and necrosis appeaared in the pulp of the same teeth from group T1 (Figure 4). In the mesial horn of the coronary part of this pulp, a strong inflammatory infiltrate could be seen. The outer parts of the teeth were intact, although, besides the pulp, damage to the primary dentine was partially present. Vacuolisation of pulp cell cytoplasm, and a vast small-grained infiltration were visible. Like the rest of the elements of the pulp, odontoblasts could not be recognized because of the necrosis. 


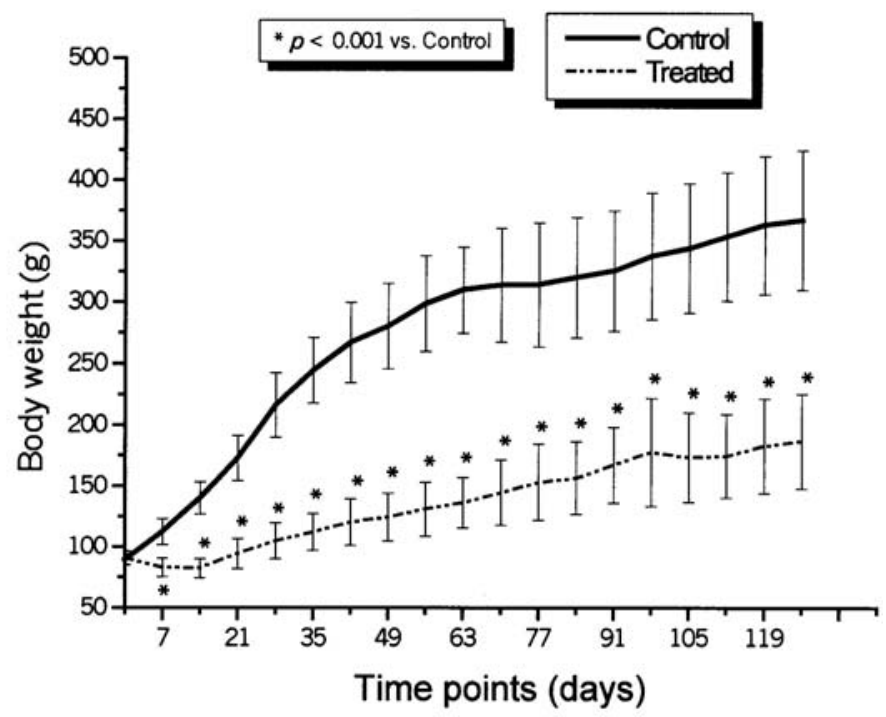

Figure 1. Body weight of control and treated animals during the experiment

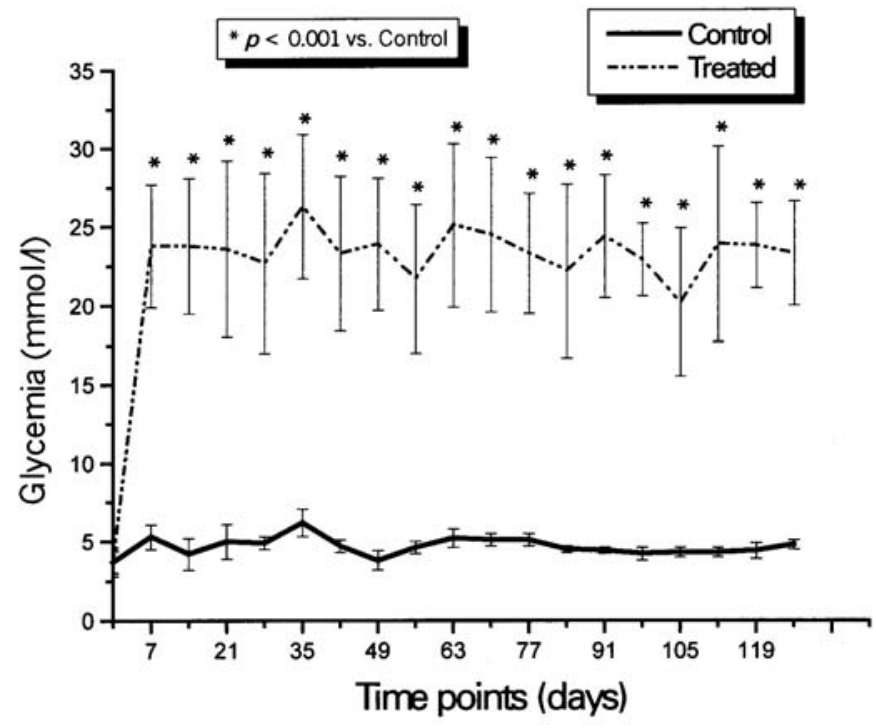

Figure 2. Glycemia in control and alloxan treated animals during the experiment 
Acta Veterinaria (Beograd), Vol. 53. No. 5-6, 343-352, 2003.

Radujković-Kuburović Gordana et al. Late morphological changes in the molar pulp of Wistar rats with alloxan induced diabetes

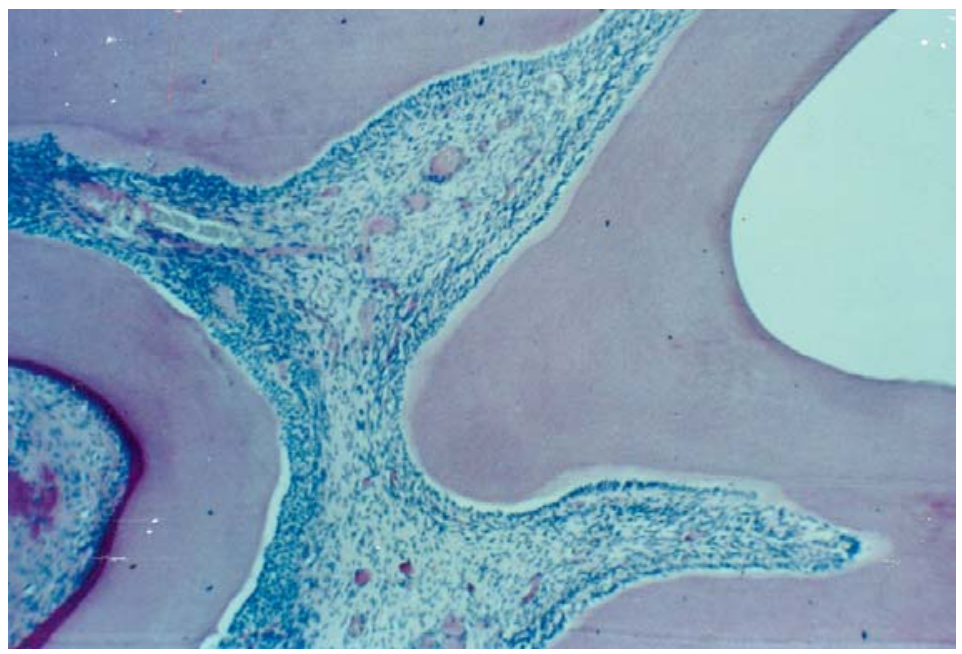

Figure 3. Pulp of the mandibular molar from group C1; PAS; 10x25

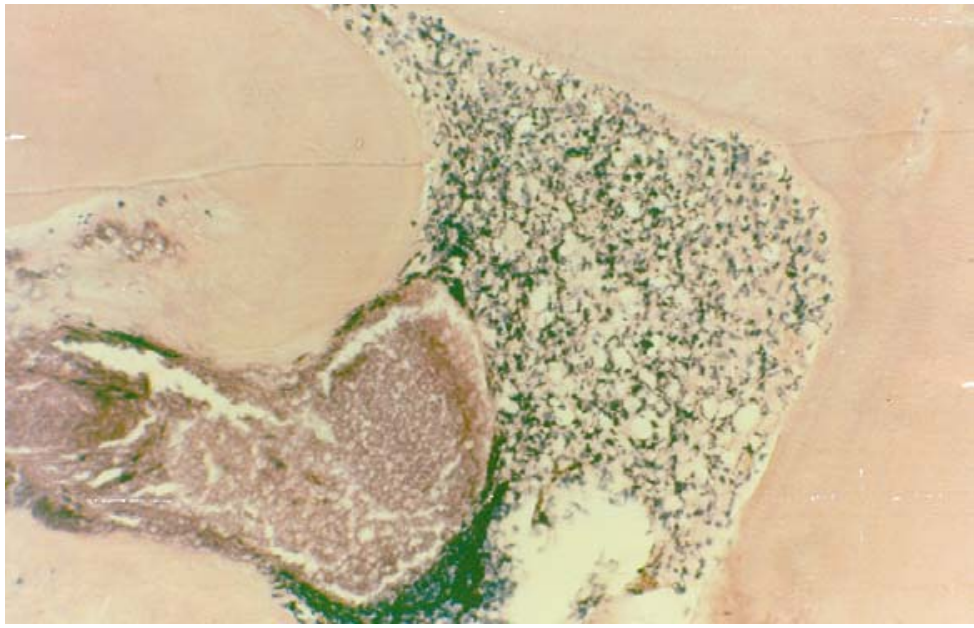

Figure 4. Pulp of the mandibular molar from group T1; HE; 10x25

Histological analysis of the same teeth from a rat from treated group T2 (Figure 5) was compared with the equivalent control (Figure 6). In the treated rat abscess forms were presented in the mesial horn of the pulp with macrophages around. There was unequal thickness and greater PAS positivity of the primary dentine. 


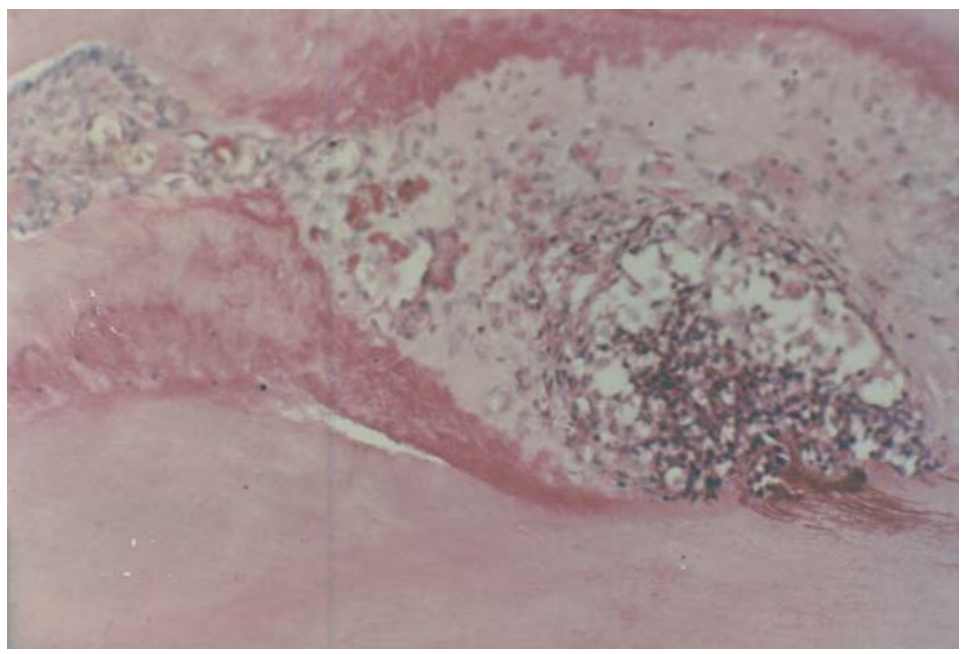

Figure 5. Pulp of the mandibular molar from group T2; PAS; 10x25x2

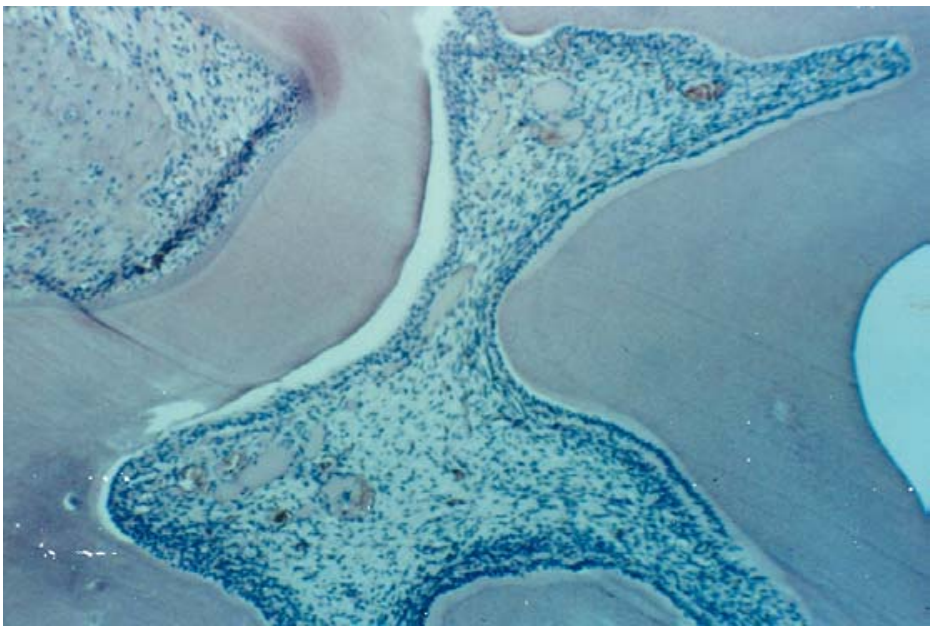

Figure 6. Pulp of the mandibular molar from group C2; Grosman Mallory; 10x25

It is interesting that the other horn of this pulp remained totally intact as well as the dentine above this horn (Figure 7).

Histological analysis of molars from group T3 were compared with pulp and dentine of the corresponding control animals (C3). The odontogen sediment was found to keep its proper disposition, but the odontoblasts themselves showed de- 
Acta Veterinaria (Beograd), Vol. 53. No. 5-6, 343-352, 2003.

Radujković-Kuburović Gordana et al. Late morphological changes in the molar pulp of Wistar rats with alloxan induced diabetes

generative changes in the coronary part of the tooth molar. Their sediment was reduced to only several cell lines, and at the contact point with primary dentine we could see vacuolization of the cytoplasm. Odontoblast nuclei were hyperchromatic with expressive pycnosis (Figure 8).

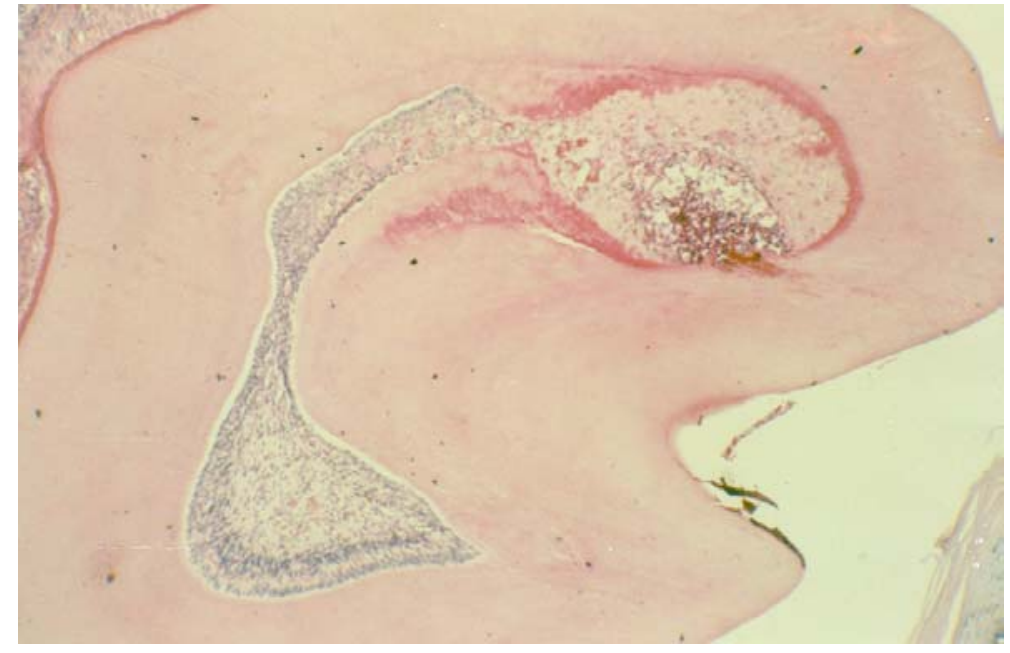

Figure 7. Pulp of the mandibular molar from group T2; PAS; $10 \times 10$

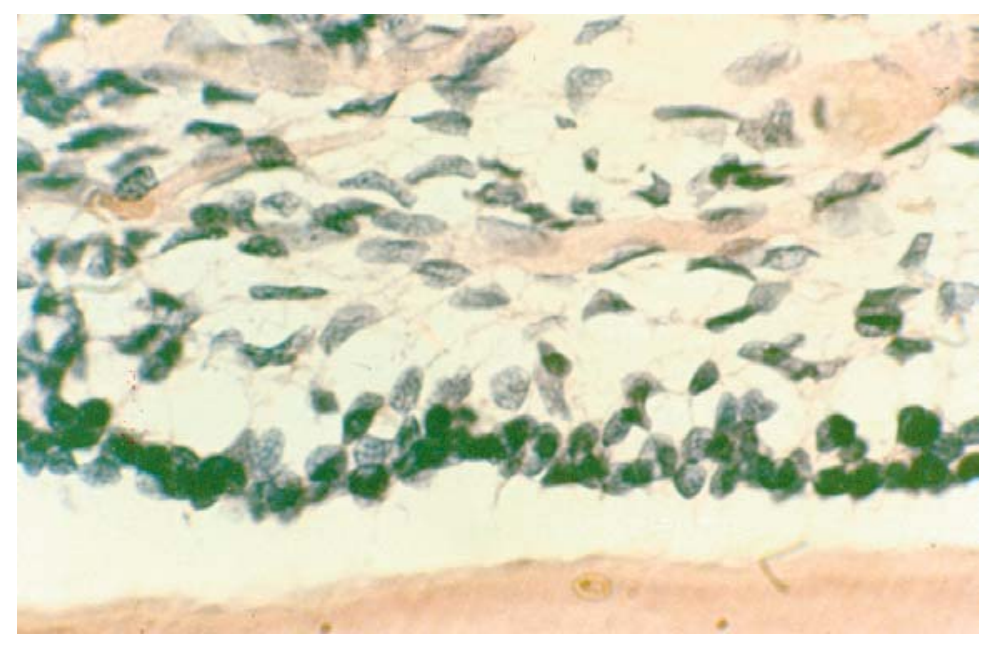

Figure 8. Pulp of the mandibular molar from group T3; PAS; 10x25x2 


\section{DISCUSSION}

The presence of hyperglycemia in the experimental animals treated with alloxan during the whole experimental period (Figure 2), could be explained as the logical consequence of an insulin deficit provoked by destruction of the endocrine pancreas, i.e. beta cells and the consequent development of diabetes. Due to the disturbed transmembranic transport of glucose, cells in the organism were "hungry", and the body weight of these animals increased slowly compared of the control group of animals, although the blood sugar level was high (Figure 1).

Besides the stasis in microcirculation, which is characteristic for early changes of the pulp in animals with alloxan diabetes (Kuburović \& Šašić,1997), we also observed stasis in large blood vessels in the molar pulp 63 days after alloxan treatment. A strong inflammatory infiltrate in the pulp could also be seen (Figure 4), which is in accordance with the finding of Cohen and Shklar (1974) and Van Buren et al. (1998), who pointed out that most diabetic animals showed partial or complete necrosis of molar pulp simultaneoisly with acute inflammatory changes. Anderson (1975) stated that necrosis of the pulp is often attached to inflammation of the pulp. Dying of the pulp tissue could be provoked by interruption of the circulation, i.e. obstruction of the blood vessels. Coagulative necrosis is the type of necrosis which usually begins by ending the blood supply and it is characterized by a protoplasmatic coagulative process. Cell structure disappears and under the microscope, in the region of necrosis, small amounts of fibrin material can usually be seen. The necrotic region may be irritant to surrounding tissue, which reacts with inflammation. Consequently, the necrotic region is surrounded by hyperemia.

Animals that were experimentally diabetic for 95 days had abscess forms only in the mesial horn of the pulp (Figure 5), while in the structure of the pulp was completely preserved in the other horn. The changed part of the pulp totally lost its normal structure and macrophages were present. Primary dentine was of unequal thickness with greater PAS positivity. The outer surface of the tooth remained intact, which indicates that the pulp abscess arose from an inflammatory process in the paradontium, or hematogenically. Cohen et al. (1974) suggest that the presence of an abscess in dental pulp is possible without a caries lesion, i.e. open pulp, and also described a pulp abscess, without open pulp, in diabetic animals. Based on their results, it may be presumed that infection proceeds hematogenically, and not per continuitatem, from the periodontium, because, otherwise, not only would the coronary part of the pulp (mesial horn) be caught sporadically, but also the radix part of the dental pulp (Figure 7).

Animals that were exposed to alloxan diabetes for 125 days showed changes in the odontoblasts, which had vacuoles in the cytoplasm (Figure 8). The nuclei of both odontoblasts and fibroblasts of pulp connective tissue were hyperchromatic with expressive pycnosis. Cell membranes were not clearly limited while the basic substance of the pulp was roughly granulated. The odontoblast stratum was not well defined and the rest of the odontoblasts were almost separated from the primary dentine. These phenomena are almost identical with those in human pulp, where vacuolisation of odontoblasts is an additional complication 
of the pulp to outer stimulation (Karadžov, 1987). It is usually the phase of hydropic transformation of the pulp in question, which can be a consequence of chronic stasis in pulp vessels. The oedema, which appears because of the increased permeability of the capilaries, presses cells aside into groups. Sometimes, vacuoles, filled with liquor, take up the greater part of the pulp, while the pulp itself is atrophic, pushed to the periphery against the dentine wall as a narrow ribbon.

The histological findings in this study are in agreement with those of Boghelli (1966), Burket (1965), Cohen et al. (1971), Cohen and Shklar (1974), Russel (1967) and Van Buren et al. (1998), while they are directly opposite to those of Bissad et al. (1969) and Bissad et al. (1970), who detected no differences in vascularisation of the pulp in diabetic persons or Sprague-Dawley rats with alloxan diabetes, compared to normal pulp.

Address for correspondence:

Dr Radujković-Kuburović Gordana

Institute of Histology,

Faculty of Stomatology,

Dr Subotića, 1/IV,

11000 Belgrade, Serbia \& Montenegro

\section{REFERENCES}

1. Anderson WAD, 1975, Patologija, Naučna knjiga, Beograd, II, 1029-35.

2. Bissada NF, EI - Kafrawy AH, El-Mostehy MR, 1969, Histological study of the dental pulp in alloxan diabetes. Egypt Dent J, 15, 4, 217-26.

3. Bissada NF, Sharawy AM, 1970, Histologic study of gingival and pulpal vascular changes in human diabetics. Egypt Dent J, 16, 4, 283-96.

4. Borghelli RF, 1966, Dental caries in diabetic and prediabetic rats, J Dent Res, 45, 1105-09.

5. Burket LW, 1965, Oral Medicine, 5th ed, Philadelphia, JB, Lippincott.

6. Cohen DW, Friedman LA, Shapiro J, Kyle GC, Franklin S, 1971, Diabetes mellitus and periodontal disease. Three-year longitudinal observations, part II. IADR Program and abstracts of papers, 616.

7. Cohen MM, Shklar G, 1974, The effect of systemic disorders on the dental pulp in experimental animals. Oral Surg Oral Med Oral Pathol, 37,5, 773-82

8. Devecerski M, 1982, Diabetes Mellitus, Savremena administracija, Beograd

9. Engels W, vanBilsen M, Wolffenbuttel BHR, vanderVusse GJ, Glatz JFC, 1999, Cytochrome P450, peroxisome proliferation, and cytoplasmic fatty acid binding protein content in liver, heart and kidney of the diabetic rat. Mol Cell Biochem, 192, 1-2, 53-61.

10. Hopfner RL, McNeill JR, Gopalakrishnan V, 1999, Plasma endothelin levels and vascular responses at different temporal stages of streptozotocin diabetes. Eur J Pharmacol, 374, 2, 221-7.

11. Karađov O, 1987, Endodoncija, Grupa autora, Dečije novine, Beograd.

12. Kobayashi T, Kamata K, 1999, Effect of insulin treatment on smooth muscle contractility and endothelium - dependent relaxation in rat aortae from established STZ - induced diabetes. Brit $J$ Pharmacol, 127, 4, 835-42.

13. Kobayashi S, Kimura I, Fukuta M, Kotani H, Inaba K, Niwa M et al., 1999, Inhibitory effects of tetrandrine and related synthetic compounds on angiogenesis in streptozotocin-diabetic rodents. Biol Pharmaceutic Bull, 22, 4, 360-5.

14. Krahl IP, 1975, Viewing the complications of diabetes. Diab Croat, IV, 3-4

15. Kuburović G, Šašić Z, 1997, Early morphological changes in molar pulp of Wistar rats with alloxan induced diabetes. Acta Veterinaria, 47, 1, 59-70. 
16. Masuda H, Goto M, Tamaoki S, Azuma H, 1999, Accelerated intimal hyperplasia and increased endogenous inhibitors for NO synthesis in rabbits with alloxan - induced hyperglycaemia. Brit $J$ Pharmacol, 126, 1, 211-8.

17. Murat N, Kalkan S, Gidener S, 1999, Effect of verapamil on responses to endothelin-1 in aortic rings from streptozotocin-induced diabetic rats. Pharmacol Res, 40, 1, 37-40.

18. Russel BG, 1967, The dental pulp in diabetes mellitus. Acta Pathol Microbiol Scand, 70, 2, 319-320.

19. VanBuren T, Vieeming W, Krutzen MM, VandeKuil T, Gispen WH, DeWildt DJ, 1998, Vascular responses of isolated mesenteric resistance and basilar arteries from short- and long-term diabetic rats. Naunyn - Schmiedebergs, Arch Pharmacol, 358, 6, 663-70.

20. VanZwieten PA, 1999, Diabetes and hypertension: Experimental models for pharmacological studies. Clin Exp Hyperten, 21, 1-2, 1-16.

21. Wallenstein S, Zucker CL, Fleiss JL, 1980, Some statistical methods usefull in circulation research. Circulat Res, 47, 1-9.

22. Zanetti M, Sato J, Katusic ZS, OBrien T, 2000, Gene transfer of endothelial nitric oxide synthase alters endothelium-dependent relaxations in aortas from diabetic rabbits. Diabetologia, 43, 3 , 340-347

\title{
POZNE MORFOLOŠKE PROMENE U PULPI ZUBA MOLARA WISTAR PACOVA SA ALOKSANSKIM DIABETESOM
}

\author{
RADUJKOVIĆ-KUBUROVIĆ GORDANA, VUKOBRATOVIĆ S i JOVOVIĆ ĐURĐICA
}

\section{SADRŽAJ}

Cilj ovog rada je bio ispitivanje poznih promena na pulpi zuba pacova sa eksperimentalnim dijabetom. Eksperiment je izveden na 36 muških albino pacova, starih 35 dana, telesne mase $89.45 \pm 9.95 \mathrm{~g}$. Životinje su bile podeljene u 6 grupa. Prva (T1), treća (T2) i peta (T3) grupa životinja primila je jednokratnu dozu aloksan tetrahidrata, približno oko $80 \mathrm{mg} / \mathrm{kg}$ mase tela. Neposredno pre aplikacije, supstanca je rastvorena u fiziološkom rastvoru i svakoj životinji je dat $1 \mathrm{ml}$ rastvora u repnu venu. Druga (C1), četvrta (C2) i šesta (C3) grupa životinja bile su kontrolne grupe i dobijale su $1 \mathrm{ml}$ čistog fiziološkog rastvora. Jednom nedeljno merena je telesna masa i glikemija. Životinje grupe T1 i C1 su žrtvovane 63-eg dana, životinje grupe T2 i C2 95-og dana a životinje grupe T3 i C3 125-og dana eksperimenta, dekapitacijom. Za histološka ispitivanja uzeti su isečci mandibularnih molara. Rezultati histoloških ispitivanja pokazuju stazu kako u mikrocirkulaciji tako i u velikim krvnim sudovima pulpe kao i nekrozu tkiva pulpe kod životinja žrtvovanih 63-ćeg dana eksperimentalnog dijabeta. Kod nekih životinja žrtvovanih 95-og dana pored masivne nekroze pulpe, u uočavaju se abscesi lokalizovani na mezijalnom rogu. Pulpe životinja žrtvovanih 125-og dana ukazuju na hidropsnu degeneraciju pulpe sa masovnom i difuznom pojavom vakuola u odontoblastima. 